Archives of Agriculture and Environmental Science

\title{
Assessment of heavy metals pollution in surface sediments of a tidal creek in the Niger Delta, Nigeria
}

\author{
Miebaka Moslen ", Ikem K.E. Ekweozor and Nsirim-Dimkpa Nwoka \\ Department of Animal and Environmental Biology, Rivers State University, Port Harcourt, NIGERIA \\ "Corresponding author's E-mail: moslen4c@yahoo.com
}

\section{ARTICLE HISTORY}

Received: 17 January 2018

Revised received: 30 January 2018

Accepted: 19 February 2018

\section{Keywords}

Heavy metal

Niger Delta

Risk Assessment

Sediment contamination

\section{ABSTRACT}

The present investigation was carried out to assess the heavy metals pollution in surface sediments of a tidal creek in the Niger Delta, Nigeria. Sediments obtained from Azuabie creek were examined for heavy metals viz., $\mathrm{Cd}, \mathrm{Cr}, \mathrm{Pb}$ and $\mathrm{Zn}$ pollution using the Okujagu creek as a control point. Three stations were established on the Azuabie creek while the control creek had one station. Sediments samples were collected in duplicates on a monthly basis for three months (October - December, 2015) and analyzed using atomic absorption spectrophotometry. Results show that Azuabie creek had higher metal concentrations compared to the control creek with mean metal values as follows Zn: 27.5 - $293.3 \mathrm{mg} / \mathrm{kg}$; Cd: $0.0-0.6 \mathrm{mg} / \mathrm{kg}$; Cr: 2.8 - $35.7 \mathrm{mg} / \mathrm{kg}$ and $\mathrm{Pb}: 5.7-22.5 \mathrm{mg} / \mathrm{kg}$. Zn levels in sediment had significant difference $(\mathrm{p}<0.05)$ between stations which occurred thus: St $1<$ St $2=$ St $3<$ St Control. The values of Contamination factor (CF) ranged from 0.00 - 3.1 indicating low to moderate level of sediment contamination. The values of the degree of contamination computed ranged from 1.28 at the control station to 5.98 at St.1 while the PLI values generally indicated "no pollution" except at St. 3 where the values was slightly $>1$. Generally, EF and I geo values were lowest at the control station compared to other stations. The study concluded there was low to moderate level of contamination indicating heavy metal input from anthropogenic origin was found in the study area.

(C)2018 Agriculture and Environmental Science Academy

Citation of this article: Moslen, M., Ekweozor, I.K.E. and Nwoka, N.D. (2018). Assessment of heavy metals pollution in surface sediments of a tidal creek in the Niger Delta, Nigeria. Archives of Agriculture and Environmental Science, 3(1): 81-85 DOI: 10.26832/24566632.2018.0301012

\section{INTRODUCTION}

In the Niger Delta, the problem of water and sediment pollution has been of concern to all stakeholders, following the rate and extent of degeneration of the environment and water bodies by human activities, particularly from industrial and domestic sources (Daka and Moslen, 2013; Moslen and Miebaka, 2017). Coastal waters and sediment systems are vulnerable to pollution by organic, industrial and chemical pollutants/wastes from several industries and human habitats located by the banks and water fronts (Ekweozor and Moslen, 2016). Bryan and Langston, (1992) also stated that contaminated sediments are major sources of pollution in estuaries and are repositories for many different organic and inorganic contaminants which are capable of accumulating such contaminants to concentrations of concern in aquatic ecosystems. Heavy metals are often major constituents of wastes discharged into the aquatic system which ultimately deposit into the underlying sediment. Heavy metal pollution is one of the challenges of coastal water pollution due to human activities such as oil exploration and exploitation, construction and fabrication of marine boats, disposal of industrial and domestic wastes and sailing (Moslen and Miebaka, 2016, 2017). Studies had also observed that heavy metals are significant environmental pollutants and their toxicity is a problem of increasing significance for ecological, evolutionary, nutritional and environmental reasons (Jaishankar et al., 2014; Nagajyoti et al., 2010). A metropolitan creek (Azuabie creek) in Port Harcourt city is one of such creeks that is prone to both industrial and domestic wastes discharges. Daka and Moslen (2013) had identified major waste inputs into the creek to include run-off from surrounding lands, animal wastes from a major abattoir, human/domestic waste from a high density settlements along 
the creek and industrial effluents from Trans-Amadi industrial area, hosting a number of manufacturing and oil servicing companies. Daka et al. (2007) had a comparative study of the sediment quality and characteristics of Azuabie and Obufe creeks and established that anthropogenic and industrial activities led to lower relative quality of the Azuabie creek. Moslen and Daka (2014) also reported that the distribution/pattern of macro invertebrate assemblage was strongly related to salinity gradient, sediment composition/characteristics and anthropogenic influence within the Azuabie creek. This work further examined sediment pollution using indices such as contamination factor (CF), enrichment factor (EF), Degree of contamination (Cd) and pollution load index (PLI) and geo-accumulation Index ( $\left.\mathrm{I}_{\text {geo }}\right)$.

\section{MATERIALS AND METHODS}

\section{Study area}

The study was done on Azuabie and the Okujagu creeks. The creeks are tidal in nature and located in the Trans-Amadi industrial area of Port Harcourt Metropolis, Nigeria (Figure 1). The creeks have input of domestic, commercial and industrial wastes products with more into the Azuabie creek compared to the Okujagu creek. Hence, three locations were established on the Azuabie creek and a control point sited at the Okujagu axis. Sediment samples were collected in duplicates on a monthly basis for three months (October - December 2015) using an Ekman grab.

\section{Analysis of sediment for heavy metals}

Small quantities of the sediment samples were air-dried under room temperature. Then $1 \mathrm{~g}$ of each was digested with EquiaRegia (mixture of $\mathrm{HCl}$ and $\mathrm{HNO}_{3}$ in the ratio of 3:1). The digested sediment samples were filtered with $20 \mathrm{ml}$ of de-ionized water and the filtrates were stored in clean acid-washed and appropriately labeled $30 \mathrm{ml}$ sample containers. Analysis was done using Atomic Absorption Spectrophotometer, AAS (Model 210VGP BUCK Scientific, USA).

\section{Evaluation of risk associated with heavy metals in sediments}

To evaluate the degree of contamination in the sediment three ecological pollution indices were used: Enrichment Factor (EF), contamination factor (CF) and pollution load index (PLI). The enrichment factor (EF) of metals is a useful indicator reflecting the status and degree of environmental contamination (Feng et al., 2004). The EF calculations compare each value with a given background level, either from the local site, using older deposits formed under similar conditions, but without anthropogenic impact, or from a regional or global average composition (Choi et al., 2012). The EF was calculated using the method proposed by (Sinex and Helz, 1981) given as

$$
E F=\frac{\left(\frac{M e}{F e}\right)_{\text {Sample }}}{\left(\frac{M e}{F e}\right)_{\text {Background }}}
$$

Where $\left(\mathrm{MC}_{\mathrm{Fe}}\right)$ sample in the metal to Fe ratio in the sample of interest; $\left(\mathrm{Me} / \mathrm{Fe}_{\mathrm{C}}\right)$ background is the natural $(\mathrm{Me} / \mathrm{Fe})$. Iron was chosen as the element of normalization because natural sources (1.5\%) vastly dominate its input. Background level of heavy metal in crust: $\mathrm{Fe}$ (47200), Cr (90), Zn (95), Pb (20) and Cd (0.3)

\section{Contamination factor $\left(\mathrm{C}_{\mathrm{F}}\right)$}

The level of contamination of sediment by metal is expressed in terms of a contamination factor $\left(C_{F}\right)$ calculated thus: $C_{F}=C_{m}$ sample/ $C_{m}$ background where, $C_{m}$ Sample is the concentration of a given metal in sediment. $C_{m}$ background is value of the metal equals to the Average Shale Value (ASV) given by (Turekian and Wedepohl, 1961).

\section{Degree of contamination}

The degree of contamination is calculated as proposed by Håkanson (1980).

$$
C d=\sum_{i=1}^{N} C F_{i}
$$

Where $\mathrm{Cd}=$ Degree of Contamination, $\mathrm{CF}=$ Contamination Factor

Pollution load index (PLI)

Pollution load index (PLI), as a means of assessing the quality of the study area with respect to heavy metals concentration was evaluated following the method proposed by Tomlinson et al., (1980). $\mathrm{PLI}=\left(\mathrm{CF}_{1} \times \mathrm{CF}_{2} \times \mathrm{CF}_{3} \times \ldots \ldots \ldots . . . \mathrm{CF}_{\mathrm{n}}\right)^{1 / \mathrm{n}}$ (Raju et al., 2012). Where, $\mathrm{n}$ is the number of metals, $\mathrm{CF}$ is the contamination factor of individual metals

\section{Geo-accumulation index $\left(I_{\text {geo }}\right)$}

Geo-accumulation Index ( $\left.\mathrm{I}_{\text {geo }}\right)$ compares current concentration of heavy metals with pre-industrial level. The geo-accumulation index $\left(I_{\text {geo }}\right)$ values were calculated for the different metals using

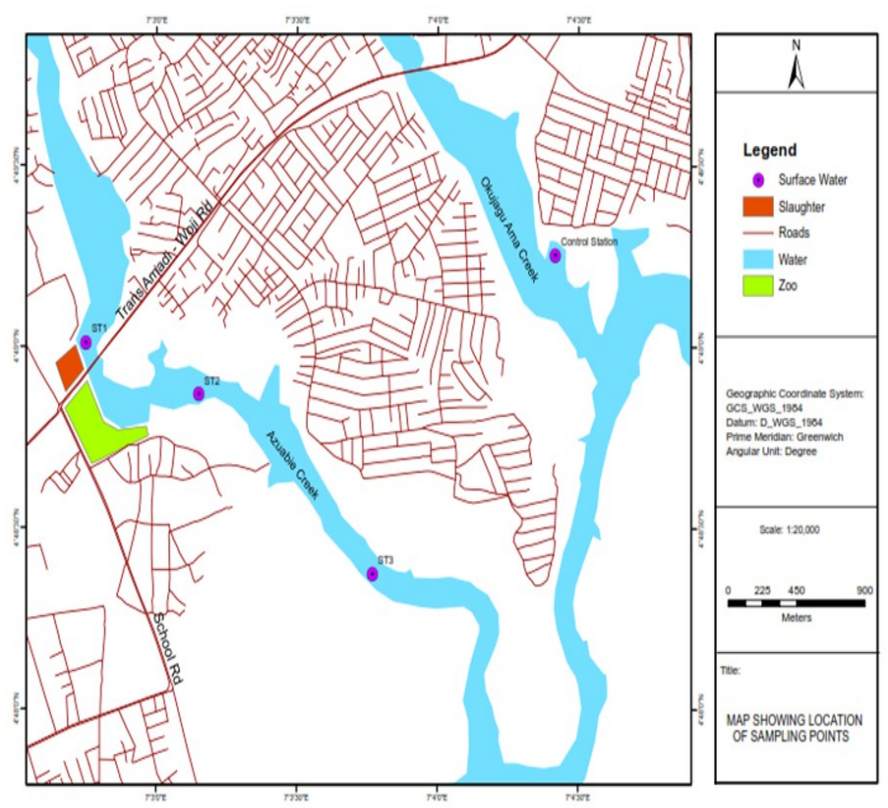

Figure 1. Map of study area showing sampled points. 
the equation of Muller (1969).

$$
I_{\text {geo }}=\log _{2}\left[\frac{c_{\text {mample }}}{\left(1.5 \times C_{m} \text { Background }\right)}\right]
$$

Where: $C_{m}=$ measured concentration of element $\mathrm{m}$ in the sediments sample, $C_{m}$ Background = geochemical background for the element $m$.

The factor 1.5 is used to compensate for possible variations with respect to background lithological variations. Muller (1981) proposed seven classes of Igeo-accumulation index. Class 6 is an open class and comprises all values of the index higher than Class 5 . Igeo of 6 indicates almost 100 fold enrichment above background value. In these computations, Average shale value (ASV) by Turekian and Wedepohl, (1961) in mg/kg $\{\mathrm{Cr}$ (90), Zn (95), Cu (45), $\mathrm{Pb}$ (20), Mn (850) and $\mathrm{Ni}(68)$, As (13), Cd (0.3), Fe (47,200), Co (19) $\}$ was considered as the background values to estimate $I_{\text {geo. }}$

\section{RESULTS AND DISCUSSION}

The mean concentration of heavy metals in sediments of the study area showed variations across the sites studied with least values observed at the control station (Figure 2). The ranges were as follows Zn: 27.5 - $293.3 \mathrm{mg} / \mathrm{kg}$, Cd: 0.0 - $0.6 \mathrm{mg} / \mathrm{kg}, \mathrm{Cr}$ : 2.8 - $35.7 \mathrm{mg} / \mathrm{kgand} \mathrm{Pb}: 5.7$ - $22.5 \mathrm{mg} / \mathrm{kg}$. The concentration of $\mathrm{Zn}$ was higher than other metals examined, this was followed by those of $\mathrm{Cr}$ and $\mathrm{Pb}$ while $\mathrm{Cd}$ had the least value. The levels of $\mathrm{Zn}$ and $\mathrm{Cd}$ obtained in this study was comparable to those (135.6 \& $0.423 \mathrm{mg} / \mathrm{kg}$ ) while $\mathrm{Cr}$ and $\mathrm{Pb}$ levels obtained in this study were less than those $(76.4 \& 37.0 \mathrm{mg} / \mathrm{kg}$ ) respectively reported by $\mathrm{Yi}$ et al. (2011). Daka et al. (2007) recorded highest mean values of metals as Zn (214.4 mg/kg ), Pb (30.0 mg/kg), Cu (17.26 mg/kg) and $\mathrm{Cd}(0.62 \mathrm{mg} / \mathrm{kg})$ during the wet season in the study area. The variation in the level of $\mathrm{Zn}$ in sediment was significantly different $(p<0.05$ ) while the concentrations of $\mathrm{Cd}, \mathrm{Cr}$ and $\mathrm{Pb}$ in sediment did not differ significantly $(p>0.05)$ between the stations examined (Table 1 ). Tukey test showed that the significant difference occurred thus: St $1<$ St2 = St3 < St Control. In another study of a dredging site in the Niger Delta, Moslen and Daka (2014) reported that the concentration of heavy metals (Arsenic, Cadmium, Chromium, Copper, Iron, Mercury, Lead, Zinc, Vanadium and Nickel) were higher downstream of the dredging position due to the remobilization of sediment-bound metals as a result of dredging activities. Also, the value of $\mathrm{Cd}$ concentration obtained in this study accords with the 0.1332 $0.6229 \mathrm{mg} / \mathrm{kg}$ range recorded at Abonema shoreline (Ideriah et al., 2012) in the Niger Delta.

Risk assessment of heavy metals in sediment

Measurement of contamination indication were done with indices such as Contamination factor (CF), Degree of Contamination (Cd), Pollution load Index (PLI), Enrichment Factor (EF) and Geo-accumulation Index ( $\left.I_{\text {geo }}\right)$, for the assessment of the risk of heavy metals in sediments collected from the study area.. Calculated values of the pollution indices are presented in Tables 2-4. The values of Contamination factor (CF) ranged from 0.00 - 3.1.
$\mathrm{Cd}$ had the least at St. 2 while $\mathrm{Zn}$ had the highest at St.1. $\mathrm{Cr}$ generally had the least CF values among the metals while the control station generally had the lowest CF values across the stations examined. The CF values obtained indicated low to moderate level of contamination. The values of the degree of contamination computed ranged from 1.28 at the control station to 5.98 at St. 1 while the PLI for the heavy metals was lowest (0.00) at St.2 and highest (1.14) at St.3. Saha and Hossain (2011) reported contamination factor (CF) of $\mathrm{Pb}, \mathrm{Cd}, \mathrm{Cu}$ and $\mathrm{Zn}$ that were responsible for considerable contaminations of sediments in their study. However, Goher et al. (2014) in a metal pollution assessment study reported CF thus: $\mathrm{Zn}$ (0.732), $\mathrm{Cr}$ (0.324), $\mathrm{Pb}$ (0.545) and $\mathrm{Cd}(0.585)$. Elias et al. (2014) reported values of degree of contamination between < 8 - 43.2 for low and very high degree of contamination respectively. The PLI values generally indicated "no pollution" except at St. 3 where the values was slightly $>1$. Salah et al., (2012) recorded PLI values between $0.45-1.15$ at all sampling sites which they suggested no overall pollution of site quality.

In order to know the possible natural or anthropogenic input and impact in sediments, enrichment factor (EF) was computed. Generally, EF values were lowest at the control station compared to other stations (Table 3). The EF of $\mathrm{Cr}$ ranged from 0.03 at St. control to 0.4 at St. 3 while those of $\mathrm{Zn}$ differed between 0.29 at St. control to 3.09 at St.1. Similarly $\mathrm{Cd}$ and $\mathrm{Pb}$ had the lowest EF value $(0.67 \& 0.29)$ at the control station and the highest at St.1 (1.33 \& 1.34) respectively. The result of enrichment factor revealed depletion to moderate enrichment. A considerable show of depletion to moderate level of enrichment from anthropogenic input was recorded for $\mathrm{Zn}(0.29$ - 3.09), Cd (0.67 -1.33) and $\mathrm{Pb}(0.29-1.34)$ which is comparable to the findings of Mamat et al. (2016) but Elias et al. (2014) reported EF values between 1.1 - 7.2 for surface sediments with $\mathrm{Cd}$ showing enrichment at some stations while $\mathrm{Cr}, \mathrm{Pb}$ and $\mathrm{Zn}$ were within background levels. Daka et al. (2007) had earlier reported the following range of EF values in the study area $\mathrm{Zn}(0.3-5.1), \mathrm{Pb}(0.6$ 3.9), $\mathrm{Cu}(0.9$ - 4.4) and $\mathrm{Cd}(0.1$ - 2.3) which could also compare with results obtained in the current study. The contamination levels of sediment heavy metal were evaluated by comparing present contaminations with background levels using the Muller scale for $I_{\text {geo }}$. The $I_{\text {geo }}$ of metals in sediments is given in Table 4. Values for each metal were as follows $\mathrm{Cr}$ : 0.006 - 0.08; Zn: 0.06 0.62; Cd: $0.00-0.40 ; \mathrm{Pb}: 0.06-0.27$. Observation shows that values of $\mathrm{I}_{\text {geo }}$ were generally lowest at the control station. The results revealed that all metals showed an I geo less than 1 , indicating that the sediment was uncontaminated to moderately contaminated. The Igeo values in this study for $\mathrm{Cd}$ and $\mathrm{Pb}$ accords with those of Mamat et al. (2016) who also reported low to moderate pollutions for the said metals but found $\mathrm{Zn}$ and $\mathrm{Cr}$ under 'no pollution status' in their study of surface sediments. $\mathrm{Li}$ (2014) reported geoaccumulation indices $\left(I_{g e o}\right)$ that suggested the magnitude of heavy metal pollution of the sediment of Yanghe River decreased in the order of $\mathrm{Cd}>\mathrm{Zn}>\mathrm{Pb}>\mathrm{Cr}>\mathrm{Ni}$. According to Saha and Hossain (2011) $I_{\text {geo }}$ index was used to ascertain moderately polluted condition for $\mathrm{Pb}, \mathrm{Cd}, \mathrm{Cu}, \mathrm{Zn}$ in the sediments quality. 
Table 1. ANOVA with F-values for sediment concentrations of heavy metals.

\begin{tabular}{ll}
\hline Heavy metals & Location (F-values) \\
\hline Sediment & $7.03^{*}$ \\
Zn & $1.00^{\text {ns }}$ \\
$\mathrm{Cd}$ & $4.32^{\mathrm{ns}}$ \\
$\mathrm{Cr}$ & $4.32^{\mathrm{ns}}$ \\
$\mathrm{Pb}$ & $*=\mathrm{P} \leq 0.05, \mathrm{~ns}=$ (not significant) \\
Key & \\
\hline
\end{tabular}

Table 2. Contamination Factor (CF), Degree of contamination $\left(\mathrm{C}_{\mathrm{d}}\right)$ and Pollution load index of metals across study sites.

\begin{tabular}{lcccccc}
\hline Station & CF $(\mathrm{Cr})$ & CF $(\mathrm{Zn})$ & $\mathrm{CF}(\mathrm{Cd})$ & $\mathrm{CF}(\mathrm{Pb})$ & Degree of Contamination $\left(\mathrm{C}_{\mathrm{d}}\right)$ & $\mathrm{PLI}$ \\
\hline St1 & 0.02 & 3.1 & 1.33 & 1.35 & 5.98 & 3.13 \\
St2 & 0.02 & 2.11 & 0.00 & 1.00 & 5.45 & 0.00 \\
St3 & 0.40 & 2.00 & 2.00 & 1.05 & 1.28 & 1.14 \\
St control & 0.03 & 0.29 & 0.67 & 0.29 & 0.20 \\
\hline
\end{tabular}

[PL1 = Pollution load index, $\mathrm{C}_{\mathrm{d}}=$ Degree of contamination, $\mathrm{CF}=$ Contamination factor, $\mathrm{CF}<1$ (Low contamination), $1 \leq \mathrm{CF}<3$ (Moderate contamination), $3 \leq \mathrm{CF}<6$ (Considerable contamination), CF > 6 (Very high contamination), $\mathrm{PLI}<1$ (No pollution), PLI >1 (Pollution/site deterioration) PL1 = 1 (Baseline levels).].

Table 3. Enrichment factor (EF) of heavy metals in sediments.

\begin{tabular}{lcccc}
\hline Station & $\mathrm{Cr}$ & $\mathrm{Zn}$ & $\mathrm{Cd}$ & $\mathrm{Pb}$ \\
\hline St1 & 0.02 & 3.09 & 1.33 & 1.34 \\
St2 & 0.18 & 2.12 & 0.03 & 1 \\
St3 & 0.4 & 2 & 2 & 1.13 \\
St control & 0.03 & 0.29 & 0.67 & 0.29 \\
\hline
\end{tabular}

[EF $<2$ (Depletion to moderate enrichment), $2 \leq \mathrm{EF}<5$ (Moderate enrichment), $5 \leq \mathrm{EF}<20$ (Significant enrichment), $20 \leq \mathrm{EF}<40$ (Very high enrichment), $\mathrm{EF}<40$ (Extremely high enrichment)].

Table 4. Geo-accumulation Index (I $\left.\mathrm{I}_{\text {geo }}\right)$ of heavy metals in sediment.

\begin{tabular}{lcccc}
\hline Station & $\mathrm{Cr}$ & $\mathrm{Zn}$ & $\mathrm{Cd}$ & $\mathrm{Pb}$ \\
\hline St1 & 0.004 & 0.62 & 0.27 & 0.27 \\
St2 & 0.04 & 0.42 & 0.00 & 0.2 \\
St3 & 0.08 & 0.40 & 0.40 & 0.23 \\
St control & 0.006 & 0.06 & 0.13 & 0.06 \\
\hline
\end{tabular}

$\left[I_{\text {geo }}<0\right.$ (Practically uncontaminated), $I_{\text {geo }}<1$ (Uncontaminated to moderately contaminate), $I_{\text {geo }}<2$ (Moderately contaminated), $2<I_{\text {geo }}<3$ (Moderately to heavily contaminated), $3<\mathrm{I}_{\mathrm{geo}}<4$ (Heavily contaminated), $4<\mathrm{I}_{\mathrm{geo}}<5$ (Heavily to extremely contaminated), $5<\mathrm{I}_{\mathrm{geo}}<6$ (Extremely contaminated)].

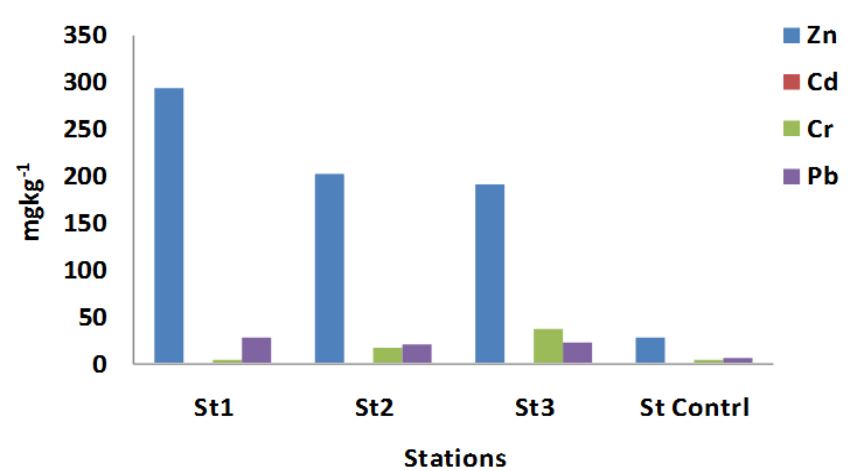

Figure 2. Variations of heavy metal concentration in sediments across stations.

\section{Conclusion}

In this study sediment samples from two adjacent creeks in the upper Bonny estuary were examined. The results indicated higher concentration of heavy metals $(\mathrm{Zn}>\mathrm{Cr}>\mathrm{Pb}>\mathrm{Cd})$ at stations within the Azuabie creek compared to the control creek (Okujagu). ANOVA showed significant difference in the concentration of heavy metals between the sites examined. Stations within the Azuabie creek had significantly different metal concentration compared to the control site which is traceable to higher anthropogenic activities within the Azuabie creek. Values of contamination factor, degree of contamination and pollution load index were higher at stations within the Azuabie creek compared to the control creek. Values of other ecological risk assessment indicators (enrichment factor and geo-accumulation index) also peaked at stations within the Azuabie creek particularly, at station 1 and 3 suggesting such sites as hotspots. EF values also suggested traces of heavy metals input due to human activities hence regular monitoring is required The study therefore concluded that the sediment status of the study area is of low to moderate level of contamination. This study therefore, serves as basis for future reference and studies.

Open Access: This is open access article distributed under the terms of the Creative Commons Attribution License, which permits unrestricted use, distribution, and reproduction in any medium, provided the original author(s) and the source are credited. 


\section{REFERENCES}

Bryan, G.W. and Langston, W.J. (1992). Bioavailability, accumulation and effects of heavy metals in sediments with a special reference to United Kingdom estuaries: A review. Environmental Pollution, 76: 89-131; https:// doi.org/10.1016/0269-7491(92)90099-V.

Choi, K., Kim, S., Hong, G. and Chon, H. (2012). Distribution of heavy metals in the sediments of South Korean Harbors. Environment Geochemical Health, 34(1): 71-82; DOI 10.1007/s10653-011-9413-3

Daka, E.R., Moslen, M., Ekeh, C.A. and Ekweozor, I.K.E. (2007), Sediment status of two creeks in the upper bonny estuary, Niger Delta, in relation to urban/industrial activities. Bulletin of Environmental Contamination and Toxicology, 78: 515521; DOI 10.1007/s00128-007-9151-5

Daka, E.R. and Moslen, M. (2013). Spatial and temporal variation of physicochemical parameters of sediment from Azuabie creek of the upper Bonny estuary, Niger Delta. Research Journal of Environmental and Earth Sciences, 5(4): 291-228.

Ekweozor, I. K. E. and Moslen, M. (2016). Abundance and diversity of plankton of Ekerekanaand Okochiri Creeks in the Upper Bonny Estuary. Nigeria. Nigerian Journal of Oil and Gas Technology,(2): 144-155.

Elias, Md. S., Hamzah. M.S., Rahman, S. Ab., Salim, N.A.A.S., Siong, W.B. and Sanuri, E. (2014). Ecological risk assessment of elemental pollution in sediment from Tunku Abdul Rahman National Park, Sabah. Advancing Nuclear Research and Energy Development. AIP Conf. Proc. 1584, 196-206 (2014); DOI: 10.1063/1.4866131

Feng, H., Han, X., Zhang, W. and Yu, L. (2004). A preliminary study of heavy metal contamination in Yangtze River intertidal zone due to urbanization. Marine Pollution Bulletin, (49):910-915, https://doi.org/ 10.1016/j. marpolbul. 2004.06.014

Goher, M.E., Farhat, H.I., Abdo, M.H. and Salem, S.G. (2014). Metal pollution assessment in the surface sediment of Lake Nasser, Egypt. Egyptian Journal of Aquatic Research, (40): 213-224

Håkanson, L. (1980). An ecological risk index for aquatic pollution control of sediment ecological approach. Water Research, 14: $975 \mathrm{e} 1000$.

Ideriah, T.J.K., David-Omiema, S. and Ogbonna, D.N. (2012). Distribution of heavy metals in water and sediment along Abonnema Shoreline, Nigeria.Resources and Environment, 2(1): 33-40.

Jaishankar, M., Tseten, T., Anbalagan, N. Mathew, B.B. and Beeregowda, K.N. (2014). Toxicity, mechanism and health effects of some heavy metals. Interdisciplinary Toxicology, 7(2): 60-72.

Mamat, Z., Haximu, S. and Zhang, Z. (2016). An ecological risk assessment of heavy metal contamination in the surface sediments of Bosten Lake, northwest China. Environmental Science and Pollution Research, 23(8): 7255-7265. doi:10.1007/s11356-015-6020-3
Moslen, M. and Daka, E.R. (2014). Attributes of the subtidal macrobenthos of Azuabie Creek in the upper Bonny Estuary, Niger Delta, Nigeria. Research Journal of Environmental and Earth Sciences, (6): 143-155.

Moslen, M. and Daka, E.R. (2014). Effects of aggregate extraction on the physico-chemical variables of surface water of Orashi River in the Niger Delta, Nigeria. The Proceedings of the International Conference on Oceanography, Calabar, 12-14 November 2013.pp. 272 - 284.

Moslen, M. and Miebaka, C.A. (2016). Temporal Variation of heavy metal concentrations in sp obtained from Azuabie Creek in the Upper Bonny Estuary, Nigeria. Current Studies in Comparative Education, Science and Technology, 3(2): 136-147.

Moslen, M. and Miebaka, C.A. (2017). Length-weight relationship and condition factor of Mugilcephalus and Oreochromisniloticus from a Tidal creek in the Niger Delta, Nigeria. Archives of Agriculture and Environmental Science, 2(4): 287292, DOI: $10.26832 / 24566632.2017 .020406$

Muller G. (1969). Index of geoaccumulation in sediments of the Rhine River. Geology Journal 2(3): 108-118.

Nagajyoti, P.C., Lee, K.D. and Sreekanth, T.V.M (2010). Heavy metals, occurrence and toxicity for plants: a review. Environmental Chemistry Letters, 8(3): 199-216; DOI 10.1007/ s10311-010-0297-8

Raju, K.V., Somashekar, R. and Prakash, K.(2012). Heavy metal status of sediment in river Cauvery, Karnataka. Environmental Monitoring and Assessment, 184 (1): 361-373; DOI: 10.1007/s10661-011-1973-2.

Saha, P.K. and Hossain, M.D. (2011).Assessment of heavy metal contamination and sediment quality in the Buriganga River, Bangladesh. 2011 2nd International Conference on Environmental Science and Technology, IPCBEE vol.6 (2011) (C) (2011) IACSIT Press, Singapore

Salah, E.A.M., Zaidan, T.A. and Al-Rawi, A.S. (2012). Assessment of heavy metals pollution in the sediments of Euphrates River, Iraq. Journal of Water Resource and Protection, 4(12): 1009-1023, DOI: 10.4236/jwarp.2012.412117

Sinex, S. and Helz, G. (1981). Regional geochemistry of trace elements in Chesapeak Bay sediments. Environmental Geology, 3(6): 315-323.

Turekin, K.K. and Wedepohl, K.H. (1961). Distribution of the elements in some major units of the earth crust. Bulletins of Geological Society of America, (72): 175-192.

Tomlinson, D.L., Wilson, J.G., Harris, C.R. and Jeffney, D.W. (1980).Problems in the assessment of heavy metal levels in estuaries and the formation of pollution index. Helgol. Wiss. Meeresunters, (33): 566-572

Yi, Y., Yang, Z. and Zhang, S. (2011). Ecological risk assessment of heavy metals in sediment and human health risk assessment of heavy metals in fishes in the middle and lower reaches of the Yangtze River basin. Environmental Pollution, (159): 2575-2585, https://doi.org/10.1016/j.envpol. 2011.06.011 